DOI 10.18699/SBB-2020-49

\title{
Эффект использования полных митохондриальных геномов и их отдельных фрагментов для делимитации видов
}

Болбат А.В. ${ }^{1 *}$, Болбат Н.Б. ${ }^{1}$, Васильев Г.В. ${ }^{2,}$ Богданова В.С. ${ }^{2}$, Матвеенко Е.Ю. ${ }^{1}$, Кайгородова И.А. ${ }^{1}$

${ }^{1}$ Лимнологический институт СО РАН, Иркутск, Россия

${ }^{2}$ Институт цитологии и генетики СО РАН, Новосибирск, Россия

*e-mail: bolbatav@lin.irk.ru

Ключевые слова: митохондриальный геном, cox1, 12S, делимитация видов

Мотивация и цель: Сегодня для идентификации биологических видов приобретают популярность молекулярно-генетические методы. Цель данной работы - изучить влияние длины генетической последовательности на эффективность методов молекулярной делимитации таксонов.

Meтоды и алгоритмы: 50 полных митохондриальных последовательностей кольчатых червей были выровнены последовательным использованием MARS и Muscle. Фрагменты универсальных маркерных последовательностей coxl (700 н.п.) и 12S pРНК (430 н.п.) были выбраны из этого массива. Филогения реконструирована BEAST2 с параметрами, рекомендованными jModelTest2. Для детекции оперативных таксономических единиц (ОTЕ) использован GMYC.

Результаты: Древо на основе полных митогеномов показало наибольшее совпадение порядка ветвления с современной классификацией. coxl-филогения демонстрирует некоторые отличия на уровне отрядов, сохранив корректной кластеризацию подклассов. При реконструкции филогении по гену $12 \mathrm{~S}$ кластеризация была нарушена вплоть до уровня классов. Алгоритм GMYC выявил прямую зависимость числа ОТЕ от длины последовательности: 17, 41 и 49 для 12S, coxl и полного митогенома соответственно.

Заключение: Использование полных митогеномов для делимитации видов приводит к избыточному дроблению ОТЕ, тогда как использование коротких и вариабельных нуклеотидных фрагментов ведет к чрезмерной группировке. Общепринятый для использования в ДНК-штрихкодировании фрагмент coxl продемонстрировал наилучшие результаты для разделения видов. Наиболее точные результаты реконструкции филогении были получены на основе полных геномов.

Благодарности: Работа была профинансирована за счет грантов РФФИ № 17-29-05097, 19-34-50072 и 19-34-90011. Секвенирование образцов проводилось в Центре Геномных Исследований ИЦиГ СО РАН. Сборка части митогеномов проводилась на серверах Сибирского суперкомпьютерного центра CO PAH. 